\title{
Differences in Immaterial Details: Dimensional Conversion and Its Implications for Protecting Digital Designs Under EU Design Law
}

\author{
Mikko Antikainen
}

Accepted: 22 December 2020/Published online: 21 January 2021

(C) The Author(s) 2021

\begin{abstract}
The paper considers three main questions: the legal status of digital designs from the perspective of EU design law, whether the protection is tied to the reproduction of physical products, and whether the scope of protection covers dimensional conversion such as using a 3D design in 2D form or vice versa. There are two sets of views regarding dimensional conversion: the "abstract" and the "concrete" view. These two different attitudes towards the scope of protection influence the manner in which the protectability of digital designs is assessed. In the "abstract" protection, it would not matter whether a product only exists as a digital image and not as a physical shape. In the "concrete" view, the protection of digital designs is more problematic, as the scope of protection is often tied to the reproduction of an actual physical product. The paper argues that, under CJEU jurisprudence and EUIPO practice, most of the open questions regarding the protection of digital designs and dimensional conversion can be considered as solved. The CJEU has chosen "abstract" protection over "concrete", thus broadening the scope of protection at the EU level. This means that the digital use of non-digital designs can now be seen as infringing. As a consequence, in the future, right holders should put more care into evaluating the limitations and exceptions. The paper points this out with regard to the issues that are of relevance for the gaming industry, as this is where the use of digital designs is most versatile and relevant.
\end{abstract}

Keywords Designs · EU law · Scope of protection - Limitations · Exceptions · Video games

At the time of writing, the author's research was funded by the Fairness, Morality and Equality in International and European Intellectual Property Law (FAME-IP) project.

M. Antikainen ( $\square)$

PhD Student at Hanken School of Economics, Helsinki, Finland, University Teacher at Jyväskylä University School of Business and Economics, Jyväskylä, Finland

e-mail: mikko.antikainen@jyu.fi 


\section{Introduction}

An increasing number of designs are created digitally, showing the overall appearance of a design, to the extent that they can be perfect digital copies of tangible items. Digital designs are often created with physical re-production in mind, but they may be used purely in an intangible manner. Designs such as those of icons in apps and graphic user interfaces (GUI) are examples of designs made exclusively for digital use. Another instance are video games, where the building blocks for all games are digital designs. In the software, mobile devices and video game industries, the question of protecting digital designs is becoming increasingly important, as digital designs can be easily copied and used by others. It has been argued that industrial design protection could play a role in efficiently protecting digital designs. ${ }^{1}$

At the EU level, design protection is regulated through two pieces of legislation: the Design Directive ${ }^{2}$ and the Community Design Regulation (CDR). ${ }^{3}$ A designer can opt for EU-level protection, either through the Registered Community Design (RCD) by registering a design through the European Union Intellectual Property Office (EUIPO), or forego registration and opt for it to be protected as an Unregistered Community Design (UCD). ${ }^{4}$ Despite design protection becoming increasingly important, ${ }^{5}$ its extent over digital designs is not always clear. The issues concern especially whether the protection is tied to the reproduction of physical products and whether the scope of protection covers dimensional change, such as using a $3 \mathrm{D}$ design in $2 \mathrm{D}$ form or vice versa. This paper refers to this as dimensional conversion, as digitalization and dimensional change are often tied together.

In the EU, there seem to be two sets of views regarding this dimensional conversion: the "abstract" and the "concrete view" of protection. In the "abstract" view, the protection is for the "form as such", irrespective of the object's dimensions. ${ }^{6}$ In some Member States, for example Germany, it has been taken for granted that protection is granted regardless of the dimension, and that any use of a protected 3D design in 2D form can be seen as infringing. ${ }^{7}$ In the "concrete" view, again, protection is attached to a particular article of manufacture in its actual

\footnotetext{
${ }_{1}^{1}$ McKenna and Osborn (2020), p. 395; Filitz et al. (2017), Rodrigues (2018), Sanft (2017), Ferril 2016.

2 Directive 98/71/EC of 13 October 1998 on the legal protection of designs, OJ L289/28, 28 October 1998.

${ }^{3}$ Regulation 6/2002 of 12 December 2001 on Community designs, OJ L3/1, 5 January 2002. Both the DD and CDR include almost identical sets of provisions in substance. This paper explores EU protection only from the perspective of the CDR.

${ }^{4}$ A designer can also opt for national design protection, but this is outside the scope of this paper.

${ }^{5}$ Church et al. (2019).

${ }^{6}$ Kur (2003), p. 55.

${ }^{7}$ See for example, German Federal Supreme Court, April 7, 2011 - I ZR 56/09 - ICE, GRUR 2011, 1117; Bardhele Pagenberg IP Report 2011 V, 28; in a French case, the design of an umbrella was used in a photograph. See Paris Court of Appeal, pôle 5, ch. 2, 27 Nov. 2015, S.A.S. Piganiol c/ S.A.S. Publicis Conseil et al., No. 13/21612, JurisData No. 2015-029315; Propr. Industr. No. 2, févr. 2016, comm. 13, Greffe P; also Kur (2003), p. 54.
} 
dimensions. Thus, if the design protection is originally registered for a $3 \mathrm{D}$ shape, its use in 2D would not be seen as infringing, or vice versa. This view is present especially in the $\mathrm{UK}^{8}$ and the Scandinavian ${ }^{9}$ countries, but also in the US. ${ }^{10}$ Similarly, some scholars see the lack of a physical product as at least problematic for design protection. ${ }^{11}$

These two different attitudes towards the scope of protection influence the manner in which the protectability of digital designs is assessed. In the "abstract" protection, it would not matter whether a product only existed as a digital image and not as a physical shape. In the "concrete" view, the protection of digital designs is more problematic, as the protection does not cover dimensional conversion, and the scope of protection is often tied to the reproduction of an actual physical product. This diversity in the national attitudes regarding the dimensional conversion has neither been discussed in the course of the European legislative process nor much debated in the literature. ${ }^{12}$ Nevertheless, it has continued to influence national practices.

Revisiting some aspects of design law specifically with digital designs in mind is necessary for two reasons. First, protection through design law could offer some benefits to the right holder, although copyright and trademarks are the main methods of protecting digital designs. ${ }^{13}$ Compared to copyright without formal registry, a holder of an RCD enjoys a presumption of ownership ${ }^{14}$ and validity ${ }^{15}$ in infringement proceedings. Moreover, in Europe, design protection also offers some procedural advantages. ${ }^{16}$ Design protection can be available to some designs that may not be copyrightable. ${ }^{17}$ Furthermore, compared to trademark registration, acquiring design protection is easier and faster. ${ }^{18}$ In addition, design right is less expensive to acquire, especially when the protection is sought for multiple signs in different product categories. As a result, some game companies are increasingly

\footnotetext{
${ }^{8}$ McKenna and Osborn (2020), p. 395; Mendis (2020), p. 453; Kur (2003), p. 55. See for example, Apple Computer Inc. v. Design Registry FCR [2002] ECDR 19 (Chancery Division).

9 For example, in traditional Scandinavian law, the protection was not "abstract" but limited to the use of the design in regard to the specific article for which the design was protected. See Schovsbo and Teilmann-Lock (2016), p. 421; also, Oesch et al. (2005), p. 128.

${ }^{10}$ For example, Burstein argues that in the US patented designs should be conceptualized as designs as applied to a specific type of products, not as a design per se. Burstein (2015); see also Osborn (2019), p. 179.

11 For example, McKenna and Osborn (2020), p. 395; Bently and Sherman (2014), p. 710; Margoni (2013), p. 232; Elam (2016), p. 151; Mendis (2020), p. 451.

12 See further: Kapyrina (2018), Smyth (2013), McKenna and Osborn (2020), p. 395.

13 See for example, Massa and Strowel (2003), p. 76.

14 CDR Art. 17.

15 CDR Art. 85(1).

16 The right holder may sue for infringement in a single specialized national court among the Community design courts, and the court can issue a Europe-wide injunctive order against infringement. See CDR Arts. $80,82,83$ and 89 regarding jurisdiction.

17 For example, icons, GUIs and works of applied art, provided that the design is novel and has individual character. CDR Art. 4.

18 Filitz et al. (2017), p. 11; Massa and Strowel (2003), p. 77-78.
} 
using design protection to protect their digital creations ${ }^{19}$ against slavish imitations and the copying of their game assets. ${ }^{20}$ The second reason for revisiting design law is that due to the increased use of design protection and the ease of copying physical designs digitally, game creators now need to consider whether using existing physical designs digitally could infringe on the design right. The validity of digital design registrations has already been successfully challenged on the basis of prior physical design at the EU level. ${ }^{21}$

In order to consider the problem of dimensional conversion, we need to thoroughly look at the design protection of digital designs. For this, the paper first briefly introduces digital designs and their role in video games and considers the copyright/design interface in protecting digital designs. Second, the paper considers the legal status of digital designs from the perspective of EU design law, revisiting the discourse regarding protected subject matter and the requirements of the protection of digital designs. Finally, the paper then turns to the scope of protection, examining to what extent the use of digital designs is covered by EU design law. The paper argues that under CJEU jurisprudence and EUIPO practice, most of the open questions regarding the protection of digital designs and dimensional conversion can be considered as solved. The CJEU has chosen "abstract" protection over "concrete", thus broadening the scope of protection at the EU level. This means that the digital use of non-digital designs can now be seen as infringing. As a consequence, in the future, right holders should put more care into evaluating the limitations and exceptions. The paper points this out with regard to the issues that are of relevance for the gaming industry, as this is where the use of digital designs is most versatile and relevant.

\section{Digital Design}

\subsection{Digital Designs and Video Games}

Despite being a commonly used term, "design" has eluded an exact definition. ${ }^{22}$ It can be used to refer to the technical practice, the craft or the process of creating objects. On the other hand, it is also used to describe aesthetic or functional fashion items, interiors, packaging or works of applied art. Designs may be pleasant or functional. Design can also be understood to include both digital design processes and digital designs. ${ }^{23}$ A digital design process here refers to the process of creating designs using software programs. Digital designs, which are the focus of this paper,

\footnotetext{
19 For example, the Finnish mobile game company SuperCell has acquired 37 design rights for its games, compared to its 49 trademarks. Another well-known mobile game company, King.com, famous for CandyCrush Saga and its other mobile games, has registered 852 designs and only 241 trademarks.

${ }^{20}$ McArthur (2013), Corbett (2016).

21 Case R 1948/2015-3, TeamLava, LLC v. King.com Limited, (1 December 2016) Decision of the Third Board of Appeal.

22 See for example, Brandes (2012), Rawsthorn (2008), Suthersanen (2011), Adams and Webster (2016), Heskett (2005).

23 For example, Tischner (2019), p. 166.
} 
refer to digital illustrations of objects, which are graphically represented and projected normally through a display unit, such as the screen of a computer monitor.

Digital designs should also be understood broadly. They can be in $2 \mathrm{D}$, for example designs for an icon, web design, GUI, a 2D character model or visual background. They can also be a 3D designs used in computer models or computer aided design (CAD). ${ }^{24} \mathrm{CAD}$ files are often associated with $3 \mathrm{D}$ printable CAD files, which function as blueprints for physical manufacturing. However, it is worth noting that $\mathrm{CAD}$ is not the only 3D file format, but one of several 3D modelling tools and file formats used to create digital designs, in which the purpose of use differ to some extent. Some digital designs are created with physical reproduction in mind. Others, such as digital designs for video games will never exist physically but are created only for digital use.

As in designs for a physical product, a digital design usually consists of graphic design elements such as lines, contours, shapes, colours, textures and lighting, but it can also contain moving and animated elements, which contribute to its appearance. The graphic design of a video game plays an important role as almost all video games are built on digital design. The quality of graphic design can range from pixelated art to photorealism, indistinguishable from the real world. Digital designs create the aesthetic and artistic mood and style through their character models and backgrounds for the game, but may also serve an informative and functional purpose as user interfaces and icons. The design elements in games differentiate one game from other similar games through their individual or characteristic look. Some game character designs become known worldwide ${ }^{25}$ and game companies even hire fashion designers to design clothing exclusively for their game characters. ${ }^{26}$

As digital designs are integrated as parts of many computer programs and video games, it would be tempting to treat them as computer programs. One reason why a digital design could be seen as a computer program is due to its functional elements and visual effects. A model of a car for a racing game can have moving tyres, breakable parts, dynamic lightning and animation. However, these features are most often included and determined through a game engine, such as Unreal 4, or the code. Similarly, with GUI, a designer can create a layout and appearance for a game menu, through which a player can navigate options - new game, options, high scores, etc. The functionality of these options - starting a new game, for example - is, however, determined by the code. As a consequence, the code and the design should be considered separate.

\subsection{Digital Design as Copyrightable Work}

The digitalization of designs raises questions regarding the interface between copyright and design law. Whether a work is in digital or physical form, for it to be protected through copyright, it needs to meet the standard of originality. The CJEU considers a

\footnotetext{
24 Antikainen and Jongsma (2017), p. 259-261.

25 Game designs such as characters, interface, appearance and logos can become well known among users and distinguish the them from other games. Consumers could be more willing to buy the game if they recognize the familiar design of a game character such as Super Mario, Angry Birds or Zelda.

26 See Remedy (2017).
} 
work original if it is the author's own intellectual creation, ${ }^{27}$ resulting from free creative choices that reflect the author's personality. ${ }^{28}$ These choices cannot be dictated by technical considerations, rules or constraints that leave no room for creative freedom. ${ }^{29}$ In addition, the subject matter protected by copyright must be expressed in a manner that makes it identifiable with sufficient precision and objectivity. ${ }^{30}$

If a digital design can meet the threshold of originality of copyright law, it is likely to be seen as an artistic work, thus protected through the InfoSoc Directive, rather than through the Software Directive. ${ }^{31}$ The CJEU held that a GUI does not form an expression of a computer program within the meaning of the Software Directive, and thus cannot be protected by copyright under the Software Directive. However, GUIs can be protected according to the InfoSoc Directive. ${ }^{32}$ Similarly, the CJEU has stated that "videogames ... constitute complex matter comprising not only a computer program but also graphic and sound elements, which, although encrypted in computer language, have a unique creative value which cannot be reduced to that encryption". ${ }^{33}$ The Court has further stated that "[i]n so far as the parts of a videogame, in this case, the graphic and sound elements, are part of its originality, they are protected, together with the entire work, by copyright in the context of the system established by Directive 2001/29", 34 thus, indicating that both graphics or digital designs for that matter are not computer programs even if they are implemented in videogames. This is in line with the view that a design in CAD format, for example, should not be seen as a computer program, just like Word documents, PDFs or mp3 files, which are seen as artistic works. ${ }^{35}$

Most digital designs would likely meet the requirements of originality. However, this does not mean that all digital designs would receive copyright protection. For example, GUIs and icons may be considered as copyrightable subject matter in the $\mathrm{EU}^{36}{ }^{36}$ and yet their specific design elements may lack originality and are therefore not protected by copyright in Member States' practice. ${ }^{37}$

\footnotetext{
27 Case C-5/08, Infopaq v. Danske Dagblades Forening, ECLI:EU:C:2009:465, para. 37.

28 Case C-145/10, Painer v. StandardVerlags GmbH, ECLI:EU:C:2013:138, para. 89; joined cases C-403/08 and C-429/08, Premier League Ltd and Karen Murphy, ECLI:EU:C:2011:631, para. 98; Case C-604/10, Football Dataco v. Yahoo!, ECLI:EU:C:2012:115, para. 38.

29 Joined cases C-403/08 and C-429/08, Premier League Ltd and Karen Murphy, para. 98; Case C-604/ 10, Football Dataco v. Yahoo!, ECLI:EU:C:2012:115, para. 39.

${ }^{30}$ Case C-310/17, Levola Hengelo v. Smilde Foods, ECLI:EU:C:2018:899, para. 40.

31 For more detailed discussion, see Antikainen and Jongsma (2017) pp. 266-269.

32 Case C-393/09, Bezpečnostní softwarová asociace - Svaz softwarové ochrany v. Ministerstvo kultury ECLI:EU:C:2010:816.

33 Case C-355/12 Nintendo v. PC Box, ECLI:EU:C:2014:25, para. 23.

34 Ibid. para. 23.

35 Antikainen and Jongsma (2017), p. 268.

${ }^{36}$ Case C-393/09, Bezpečnostní softwarová asociace - Svaz softwarové ochrany v. Ministerstvo kultury ECLI:EU:C:2010:816.

37 For example, from the Finnish perspective, the Finnish Copyright Council saw that a GUI was not seen as original and thus not protected by copyright, despite being a registered community design. Statement of the Finnish Copyright Council TN:2016:15; for the US perspective, see Apple Computer, Inc. v. Microsoft Corp., 35 F.3d 1435 (9th Cir. 1994).
} 
Moreover, digital designs combine creative elements and functional elements. Many countries have been reluctant to offer copyright protection for works with functional elements. ${ }^{38}$ For example, the higher threshold of originality required for works of applied art in Germany and in the Nordics has been set to avoid the cumulation of copyright and design protection. ${ }^{39}$ Such diverging approaches are no longer possible, however, as the CJEU held in Cofemel that work of applied art may not be treated differently from other work types, but copyright protection must instead be asserted through a uniform standard of originality. ${ }^{40}$ Whilst the CJEU seems to allow the cumulation of copyright and design, it also emphasizes that dual protection must not have the consequence that the respective objectives and effectiveness of those two forms of protection are undermined ${ }^{41}$ and that the concurrent protection can be envisaged only in certain situations. ${ }^{42}$

In Brompton, ${ }^{43}$ the CJEU had the opportunity to clarify some of these criteria. Here, the Court states that a subject matter satisfying the condition of originality may be eligible for copyright protection, even if its realization has been dictated by technical considerations, provided that its being so dictated has not prevented the author from reflecting his personality in that subject matter, as an expression of free and creative choices. ${ }^{44}$ If it is solely dictated by technical results, a design cannot be original. However, this is for the national courts to decide, bearing in mind all the relevant aspects of the dispute in the main proceedings. ${ }^{45}$ The CJEU also rejected the multiplicity of form theory, according to which if there are other possible shapes for a functional design, then its shape cannot be dictated by function. ${ }^{46}$ In addition, the Court seems to implicitly reject the causality theory, ${ }^{47}$ which is applicable in EU design law. $^{48}$

When applied to digital designs, a design depicting a functional object, such as a car, may be protected by both design law and copyright, yet the scope of protection is determined through different standards. Both exclude designs that are solely

\footnotetext{
38 Derclaye (2018).

39 See for example, Ohly (2018) for the German perspective; and Schovosbo and Rosenmeier (2018) for the Nordic perspective.

40 Case C-683/17, Cofemel v. G-Star Raw, ECLI:EU:C:20219:721; for a more detailed analysis of the Cofemel case, see Kur (2019), Derclaye (2020a), Schovsbo (2020).

41 Ibid. para. 51.

42 Ibid. para. 52.

43 Case C-833/18, SI, Brompton Bicycle Ltd v. Chedech/Get2Get, ECLI:EU:C:2020:461.

44 Ibid, para. 38.

45 Ibid, paras. 33 and 38.

46 Ibid. para. 35; the causality theory is also rejected in design law. See Case C-395/16 Doceram GmBH

v. Ceramtec GmBH, ECLI:EU:C:2018:172, para. 26.

47 Case C-833/18, SI, Brompton Bicycle Ltd v. Chedech/Get2Get, ECLI:EU:C:2020:461, para. 36; Derclaye (2020b).

48 Case C-395/16 Doceram GmBH v. Ceramtec GmBH, ECLI:EU:C:2018:172, para. 26.
} 
dictated by their technical function. ${ }^{49}$ In copyright, if the shapes are not solely dictated by their technical function, the designer still needs to be able express their creative abilities by making free and creative choices. ${ }^{50}$ With design protection, on the other hand, the appearance of the design needs to create a different overall impression on an informed user and its appearance should not be solely dictated by efficiency considerations. ${ }^{51}$

\subsection{The Copyright/Design Interface in Protecting Digital Designs}

When design protection seems to be almost fully cumulative with copyright, it should be asked what the role of design protection is. This is especially relevant as there are several undisputable advantages in using copyright to protect digital designs. For example, copyright is free and easy to obtain, it provides a longer term of protection and offers a broad scope of protection. ${ }^{52}$ Copyright protection also includes moral rights. All things considered, one could question why anyone should use design protection. ${ }^{53}$

At the same time, design protection does seem to have its role in protecting digital designs. For one, registered design protection offers some benefits from the registry. As mentioned above, compared to copyright without formal registry, a holder of an RCD enjoys a presumption of ownership ${ }^{54}$ and validity ${ }^{55}$ in infringement proceedings. Moreover, in Europe, design protection also offers some procedural advantages, ${ }^{56}$ as there is no need to prove that the defendant has copied the design. ${ }^{57}$ In addition, copyright and design protection for digital designs do not always overlap, but may be complementary, as design protection is available for digital designs that are not copyrightable due to a lack of originality, such as graphic icons, GUIs and digital designs depicting functional items.

In the end, as mentioned by both the AG and the CJEU in the Cofemel case, copyright and design protection pursue fundamentally different objectives and are subject to distinct rules. The purpose of design protection is to protect subject matter which, while being new and distinctive, is functional and liable to be massproduced. ${ }^{58}$ Thus, the primary objective for design protection is to bolster the capacity of industrial design to serve as a "marketing tool". 59 For example, Kur points out that copyright creates a personal relationship between the creator (author)

${ }_{49}$ CDR Art. 8(1); Case C-833/18, SI, Brompton Bicycle Ltd v. Chedech/Get2Get, ECLI:EU:C:2020:461, para. 33 .

50 Ibid. para. 38.

51 CDR Art. 6(1); Case C-395/16 Doceram GmBH v. Ceramtec GmBH, ECLI:EU:C:2018:172, para. 26.

52 See for example, Derclaye (2020a), p. 12.

53 For example, Tischner (2018).

54 CDR Art. 17.

55 CDR Art. 85(1).

56 See CDR Arts. 80, 82, 83 and 89 regarding jurisdiction.

57 CDR Art. 19.

58 Case C-683/17, Cofemel v. G-Star Raw, ECLI:EU:C:20219:721, para. 50.

59 Kur (2019), p. 9. 
and the creation (work). In design law, the focus lies on communicating the relationship established between the creation (design) and the public. ${ }^{60}$ For assessing the protectability of a design, it is crucial that it is capable of establishing this relationship and the market perspective that matters (a different overall impression on the informed user) and not the extent to which the design constitutes a personal expression of an individual author (the author's own intellectual creation).

With digital designs, a great deal can be invested in designing an appealing appearance for a GUI, an icon, a character, an item, etc., which makes a digital design different and identifiable to a consumer, in order to give a different overall impression on the informed user. The design choices in the appearance of the design are not made for the sake of expressing personality, but for the sake of marketability, thus they may not be protectable by copyright as such. However, they are still worth protecting against copying, whether the design is in a tangible or intangible form.

Further, it should be pointed out that the copyright's scope of protection does cover derivative use and dimensional conversion. For example, if a physical design meets the standard of originality, any recreation of it in digital form will constitute a reproduction for the purposes of copyright. ${ }^{61}$ On the other hand, digitally depicting a purely utilitarian design, such as a screwdriver, does not automatically make it original. The design is copyrightable only if something original has been added during the digitalization process. ${ }^{62}$ The process should not be seen as any different when someone makes a digital drawing of an existing painting. In addition, changing the dimension does not change the situation. Copying an original 2D work and transforming it into a $3 \mathrm{D}$ design can be an infringement of copyright. ${ }^{63}$

However, as will be discussed in the Sect. 5 below, the scope of protection of EU design law now extends to dimensional conversion. This makes design protection more useful for designers aiming to protect their creations in a digital format.

\section{A Digital Design According to the CDR}

Before addressing dimensional conversion in design protection, we need to consider the legal status of digital designs and to what extent they are protected subject

\footnotetext{
${ }^{60}$ Ibid. p. 9. Referring to the Green Paper on the Legal Protection of Industrial Designs (working document of the services of the Commission), [1991] III/F/5131/91-EN.

61 Antikainen and Jongsma (2017), p. 269.

62 See Antikainen and Jongsma (2017), p. 264; Osborn considers this issue extensively from the US point of view and argues similarly that a CAD file depicting an unoriginal, purely utilitarian object should not be protected through copyright, but through patents. See Osborn (2019), p. 177.

63 Ibid., p. 269; see explicitly Art. 17(3) of the UK Copyright, Designs and Patents Act 1988; see also, for instance, the German Federal Supreme Court, 4 May 2000, Case No. I ZR 256/97, GRUR 2001, 51,52 "Parfumflakon"; for example, in a Finnish case, a 3D artist claimed that he had rights for several 3D models of fantasy space ships which he had modelled for a movie. However, the Finnish Market Court did not agree with this while it was that models were done according to provided $2 \mathrm{D}$ concept pictures and process of turning a $2 \mathrm{D}$ picture into a $3 \mathrm{D}$ model was seen more mechanical work than independent creative work. Thus, the 3D artist did not receive copyright but rights belonged to the concept artist. See Decision of the Finnish Market Court MAO:302/18.
} 
matter. While the CDR defines a design through two concepts, "appearance" and "product", 64 it is important to examine what these two concepts mean in the context of digital designs. As will be discussed below, this is especially important as regards the concept of product, as it determines whether the design can be protected and whether infringement can take place.

\subsection{Appearance in a Digital Design}

The CDR does not explicitly define appearance but gives a non-exhaustive list of features, which include the lines, contours, colours, shape, texture and/or materials of the product itself and/or its ornamentation. It seems safe to assume that this broad definition of appearance also includes digital designs and the EUIPO registration practice, ${ }^{65}$ and the guidelines confirm this. ${ }^{66}$ However, there has been some uncertainty as to how far this definition extends. Some scholars have found that the concept of the appearance of a product seems to exclude dynamic elements from the scope of protection. ${ }^{67}$ In addition, it has been argued that it would be difficult to document these dynamic aspects in the registration process. ${ }^{68}$ On the other hand, others have stated that because of the broad definition of a design, it covers even moving designs such as symbols or lines moving across a computer screen. ${ }^{69}$

In practice, these concerns seem to be resolved by the EUIPO, as it gives specific guidelines for sequences of snapshots for animated designs. It states that snapshots are short sequences of views used to show a single animated design at different specific moments in time, in a clearly understandable progression. ${ }^{70}$ This applies to animated icons and animated graphic user interfaces. These animated icons or graphic user interfaces need to be visually related, which means that they must have features in common. ${ }^{71}$ Also the Board of Appeal has addressed and upheld the validity of a registered animated icon. ${ }^{72}$

\subsection{Digital Design as a Product}

The second important concept, according to the CDR, is the "product", which is defined as "any industrial or handicraft item, including inter alia part intended to be assembled into a complex product, packaging, get-up, graphic symbols and

\footnotetext{
64 CDR Art. 3.

65 See supra note 88 and accompanying text.

${ }^{66}$ For example, the EUIPO Guidelines state that the designs of screen displays and icons as well as other kind of visible elements of a computer program are eligible for registration. EUIPO (2018), p. 24.

67 Margoni (2013), p. 232.

68 Ibid. p. 232.

69 Bently and Sherman (2014), p. 707.

70 EUIPO (2018), p. 34.

71 Ibid. p. 34.

72 See for example, Case R 1950/2015-3, TeamLava, LLC v. King.com Limited, (1 December 2016) Decision of the Third Board of Appeal; Case R 1949/2015-3, TeamLava, LLC v. King.com Limited, (1 December 2016) Decision of the Third Board of Appeal.
} 
typographic typefaces but excluding computer programs". ${ }^{73}$ Although computer programs are excluded, most digital designs fall outside this exclusion. This is because the scope of the exclusion of computer programs is determined by the material covered by the copyright under the Software Directive. ${ }^{74}$

The requirement of a product in the definition of a design in CDR, however, poses some problems for digital designs. Arguably, the term "product" itself, in addition to "industrial" and "handicraft" items, may refer only to physical products. ${ }^{75}$ Such an interpretation of a "product" would exclude digital designs when they do not involve physical products. However, the fact that graphic symbols are also listed in the definition of a "product" implies that there is no clear distinction between physical and immaterial. ${ }^{76}$ As the concept of product is at the core of design protection and there are some legal and technical differences between $2 \mathrm{D}$ and $3 \mathrm{D}$ designs, it is worthwhile to examine these separately.

\subsubsection{Digital 2D Designs as Products}

With 2D designs, it is generally seen that the reference in Art. 3(b) of the CDR to graphic symbols as products also includes computer icons. ${ }^{77}$ The meaning of product can be considered to be broad, as symbols and possibly even single letters, as in the case of typographic typefaces, can be regarded as "products" within the meaning of the European design legislation. ${ }^{78}$ For example, Kur observed that graphic symbols are protected as industrial designs, even if the protection is not applied to an "article". Thus, there is no reason why discrimination should be justified between graphic designs in general and images appearing on a computer screen as the result of a program being loaded. ${ }^{79}$ Others similarly find that the inclusion of graphic symbols in the definition of product indicates that a protectable design does not need to be tied to a physical dimension. ${ }^{80}$

However, there have been different opinions among scholars as to what extent graphic symbols can be stretched and whether they can include web designs or dynamic images. Margoni sees that when sound and dynamic effects are excluded from web designs, the end result does not significantly differ from the front of a book cover. ${ }^{81}$ On the other hand, he also thinks that as a product is strictly defined as

\footnotetext{
73 CDR Art. 3(b).

74 See Sect. 2.2. above; Musker (2001), 18; Bently and Sherman (2014), p. 710.

75 McKenna and Osborn (2020), p. 395; Bently and Sherman (2014), p. 710; Margoni (2013), p. 232; Elam (2016), p. 151.

76 It could be similarly questioned whether pure artistic works such as paintings, drawings, and statues can be considered as products. On the other hand, drawing a clear boundary between art and handicraft is difficult, and EUIPO has already accepted several registrations for works such as sculptures and paintings. See Bently and Sherman (2014), p. 709.

77 Kur (2003), p. 58; Margoni (2013), p. 228; Elam (2016), p. 150; Bently and Sherman (2014), p. 711; Musker (2001), p. 18 Massa and Strowel (2003), p. 72; Stone (2016), p. 67; Shemtov (2020), p. 22.

78 Kur (2003), p. 58.

79 Ibid. p. 58.

${ }^{80}$ Elam (2016), p. 150; Margoni (2013), p. 228.

81 Margoni (2013), p. 228.
} 
an industrial or handicraft item, it should be impossible for a web design to meet such a definition. Thus, a web design should, in general, be excluded subject matter. ${ }^{82}$ Bently and Sherman see that that it is possible to protect certain aspects of web designs, but the protection of dynamic images and sound effects may be difficult. ${ }^{83}$ Regarding dynamic images, Musker seems to think that they should fall within the definition of design, to the same extent as icons and other screen displays, although the registration practice is likely to require static images. ${ }^{84}$ Elam, on the other hand, sees that design protection seems to cover all (2D) digital items - with the sole exclusion of sounds and animated images - that appear on electronic devices such as computer screens or mobile phones. ${ }^{85}$

The EUIPO states regarding icons that "[d]esigns of screen displays and icons and other kinds of visible elements of a computer program are eligible for registration (see Class 14-04 of the Locarno Classification)." ${ }^{86}$ A search in Locarno Class 14-04 (Screen displays and icons) gives a result of over 13,000 different designs. Most of these are icons for mobile apps, computer programs, or graphic user interfaces, but there are also animated icons and designs for video games. In addition, the EUIPO guideline ${ }^{87}$ and practice $^{88}$ clearly indicate that animated designs are protectable through design protection, at least to some extent. In the end, differentiating digital 2D designs on the basis of whether they are icons, GUIs, web designs or some other type of 2D digital designs which might not have been invented yet, seems rather arbitrary and restrictive. If graphic symbols are accepted to include digital icons, and thus are seen as products, and given that the EUIPO also accepts animated icons, it should be concluded that all digital 2D designs can be seen as products, as long as their appearance is visible.

\subsubsection{Digital 3D Designs as a Product}

With 3D digital designs, the situation may seem bit more complicated. However, in the end, 3D designs can be seen as protected subject matter, although there are three different interpretations on why this is so.

The first way to see this is as an analogy between graphic symbols, computer icons and digital 3D designs, thus expanding computer icons to cover all digital items. For example, icons, graphic symbols and graphic user interfaces can be created with 3D models but made to look like 2D when seen from a certain perspective. Some have already registered a 3D game model under the Locarno

\footnotetext{
82 Ibid. p. 228.

83 Bently and Sherman (2014), p. 711; Musker (2001), p. 17.

${ }^{84}$ Musker (2001), p. 18.

85 Elam (2016), p. 150.

86 EUIPO (2018), p. 24.

87 EUIPO (2018), p. 34.

${ }^{8}$ Case R 1950/2015-3, TeamLava, LLC v. King.com Limited, (1 December 2016) Decision of the Third Board of Appeal; Case R 1949/2015-3, TeamLava, LLC v. King.com Limited, (1 December 2016) Decision of the Third Board of Appeal.
} 
Class $14.04{ }^{89}$ However, in the case of 3D printable CAD files, some scholars see fundamental differences between CAD files and graphic symbols. ${ }^{90}$ For instance, Margoni sees a conceptual difference between a digital item like a "computer icon" and a spoon, represented digitally as a CAD file. ${ }^{91}$ This is because a computer icon is neither an industrial or handicraft product nor does it possess the characteristics of an object manufactured or printed into one. Its function unfolds exclusively on the computer screen as a digital immaterial item. ${ }^{92}$ A CAD design, on the other hand, which perfectly represents the appearance of a product, can most likely be deemed protectable, and its actual manufacturing is probably not necessary in order to activate the CD. ${ }^{93}$ In other words, a CAD file is protectable only when it has been created with the purpose of using it to manufacture a physical object, and thus represents that physical object. ${ }^{94}$ Elam seems to agree with Margoni. ${ }^{95}$ In addition, Mendis does not see the similarity between a graphic icon and a CAD file, as the latter contains "instructions or act[s] as a blueprint" to produce physical objects. ${ }^{96}$

Interestingly, all of these scholars emphasize the fact that the CAD file can be made into a physical object as a rationale for design protection. However, this does not apply to all 3D digital designs. Many digital models are made and used solely in a digital setting. Some cannot even exist in the physical realm. For example, the design's structure could be too fragile to exist physically. Can these kinds of digital designs be seen as graphic symbols and thus products? Margoni's description of a computer icon would encompass such designs, as they are not industrial or handicraft products, cannot be manufactured, and they function exclusively on the computer screen as digital immaterial items. ${ }^{97}$ Elam, on the other hand, sees that these kinds of "virtual products" cannot be seen as products, and that the definition of design thus should be broadened to include "immaterial" items. ${ }^{98}$

According to the second interpretation, 3D digital designs are seen as graphical representations of the design for which the protection is sought. ${ }^{99}$ Although the law is structured around the concept of "product", a design is protectable regardless of whether or not a product exists in the tangible world. ${ }^{100}$ This interpretation is deducible from EUIPO's practice. The EUIPO accepts 3D models in the form of 3D computer graphics ${ }^{101}$ as a form of visual representation of the design, in accordance

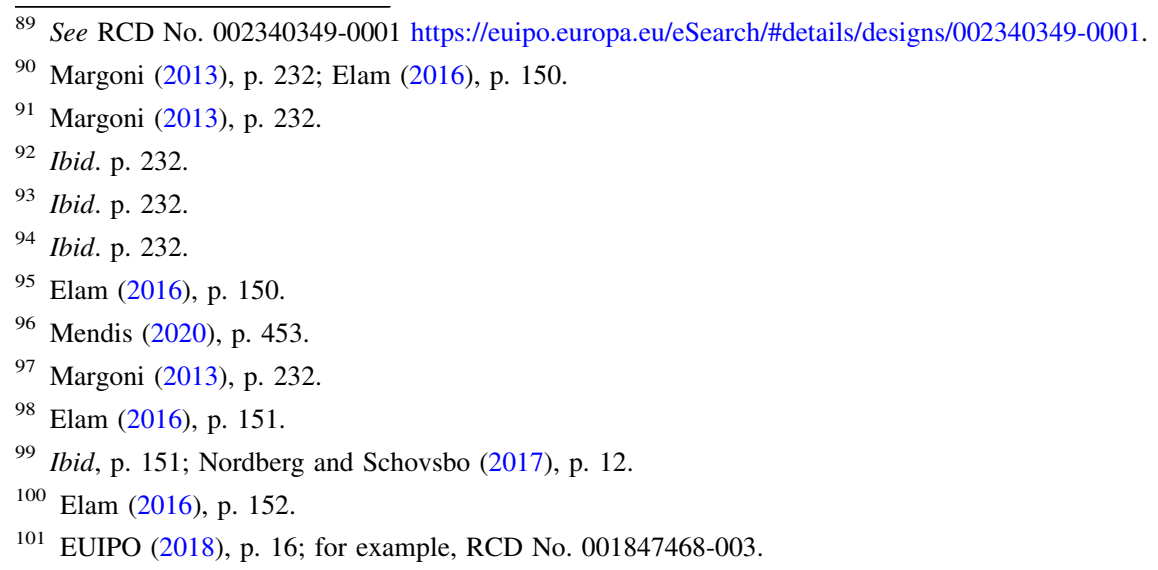


with Art. 4(1) of the Design Implementing Regulation. ${ }^{102}$ Thus, a 3D model of a game figure could be submitted to the EUIPO and be registered in Locarno Class 21.01 (Games and toys). This is what at least one game company has already done. ${ }^{103}$ The EUIPO does not examine whether the product is actually made or used, or can be made or used, in an industrial or handicraft manner. ${ }^{104}$ The EUIPO only examines whether the appearance of the "product" is disclosed in light of the design itself, in addition to whether the subject matter of the application corresponds to the definition of a design, as stated in Art. 3(a) CDR, and whether it is contrary to the public policy and the accepted principles of morality.

This implies that a digital 3D design of a product can be created through software and then included in the registration application. The designer then obtains a design registration covering the product design represented therein, irrespective of whether the product actually exists or not. It should be noted that there is uncertainty about whether courts should see CAD models in a registration application as pictures or photographs of the design. ${ }^{105}$ For example, Tischner observes CAD files more as a picture, because it is used to record the structural features of a design. ${ }^{106}$ On the other hand, it could be argued that a digital design meant for digital use could be considered to be closer to a photograph. This is because, in the video game context, the CAD is the product itself, in which its overall appearance is embodied. There are also problems of scope. As will be discussed later, during enforcement, the scope of protection and use of design may still require a connection to physical products, thus leaving purely digital use out of the scope of design protection. ${ }^{107}$

The third interpretation is to view 3D designs as blueprints or plans of an object. ${ }^{108}$ The EUIPO guidelines for examination state that "Blueprints, plans for houses or other architectural plans and interior or landscape (e.g. gardens) will be considered 'products' for the purpose of applying Article 7(1) of the Design Regulation and will be accepted only with the corresponding indication of 'printed matter' in Class 19-08 of the Locarno Classification." 109 Thus, 3D printable CAD files could be seen as registrable products. ${ }^{110}$ However, digital designs in video games do not properly fit this viewpoint as they are not first and foremost blueprints or plans to manufacture anything.

\footnotetext{
102 Commission Regulation (EC) No. 2245/2002 of 21 October 2002 implementing Council Regulation (EC) No. 6/2002 on Community designs, OJ L 341, 17.12.2002, p. 28, amended by Commission Regulation (EC) No. 876/2007 on 24 July, OJ L 193, 25.7.2007, p. 13.

103 See design number 002466391-0001 EUIPO https://euipo.europa.eu/eSearch/\#details/designs/ 002466391-0001.

104 EUIPO (2018), p. 24.

105 Tischner (2019), p. 169.

106 Ibid. pp. 169-170.

107 See Sect. 5.1 below.

108 Nordberg and Schovsbo (2017), p. 12; Elam (2016), p. 150; Mendis (2020), p. 453.

109 EUIPO (2018), p. 24.

110 Nordberg and Schovsbo (2017), p. 12.
} 
In sum, as all three suggestions seem to be less than perfect, the situation is still unclear for purely digital designs. Indeed, some clarification will be needed if digital 3D designs, as such, are to be protected with the CDR.

\section{The Requirements of Protection for Digital Designs}

A design needs to meet certain requirements of protection in order to be protected. Namely, it needs to be novel in the sense that no identical design has been made available to the public ${ }^{111}$ and the differences should not be in immaterial details. ${ }^{112}$ A design also needs to have individual character in a form so that it produces a different overall impression on the informed user. ${ }^{113}$ It is worthwhile to examine what novelty and individual character mean in the digital context.

\subsection{Making Digital Design Available to the Public}

An interesting question regarding digital designs is what qualifies as "making available to the public". This determines the pool of "prior art" against which novelty and individual character can be evaluated. In the video game context, making available normally happens through implementing a digital design in the game itself, which is then sold. However, digital designs are also used and communicated through other means. Digital designs are often included in demos, videos or screen shots, which are shared online before the game is actually released. Sometimes, for promotional purposes, gamers and streamers are given early access to games, which they stream through YouTube or Twitch.

Article 5 of the CDR sets the criterion of novelty but is restricted by Art. 7, which states that disclosing a design will lose novelty except when disclosure "could not reasonably have become known in the normal course of business to the circles specialized in the sector concerned, operating within the Community". 114 Some have suggested that disclosing a design on a web page should only be deemed to be known to the Community circles at which it was specifically aimed, not if it was merely accessible to such circles. ${ }^{115}$ For example, uploading a CAD file to a web page could be considered as public exhibition and thus form a corpus of prior art. ${ }^{116}$ This is because files are often shared on the web pages targeted at 3D printing enthusiasts and professionals. The Invalidity Division has seen as a matter of principle that disclosure on the internet forms part of the prior art, and that information disclosed on the internet is considered to be publicly available as of the

\footnotetext{
111 CDR Art. 5(1).

112 CDR Art. 5(2).

113 CDR Art. 6 (1).

114 CDR Art. 7(1).

115 Massa and Strowel (2003), p. 73.

116 Nordberg and Schovsbo (2017), p. 12 Elam (2016), p. 154.
} 
date on which the information is posted. ${ }^{117}$ The design holder claimed that the novelty of the specific GUI design for a mobile phone was not lost because of internet disclosure, since the website on which the prior design was disclosed could not be systematically searched and, thus, would remain unknown to the Community circles specialized in the sector concerned. ${ }^{118}$ The Invalidity Division did not agree, as it saw that for searches, users, be they the wider public or experts in a particular field of industry, usually use different search engines such as Google. ${ }^{119}$ By using key words, users can obtain results on websites dealing with the given subject matter. ${ }^{120}$ Therefore, the information on the internet is not irretrievable, as the holder had suggested in this case. ${ }^{121}$ Similarly, according to the Third Board of Appeal, the disclosure of a pair of Crocs clogs on the website destroyed the novelty of that design, even though the holder argued that the website was unlikely to have been found by the relevant circles in the Community because it was difficult to access. ${ }^{122}$ The Invalidity Division has also seen that even a brief exposure of a video can make a design public, since the video can be stopped and the design viewed properly without any constraints. ${ }^{123}$ Thus, it is reasonably safe to say that a design which is visible in a game, webpage or video, or streamed even for a brief time is then known to the public, as these platforms are targeted at enthusiastic fans, but also seen by competitors.

Another relevant question is whether the creation and publication of a digital design digitally is enough to trigger URCD. Contrary to the RCD, where registration can be considered as design publication, forming the basis of protected subject matter, in the case of URCD, the appearance demonstrated by the product itself forms the basis for design identification. ${ }^{124}$ It could be argued that inserting a design in a game, webpage or video, as mentioned above, is showing the design itself, and can be seen as making it available to the public. Therefore, the design is disclosed, which is enough to satisfy the requirements of URCD. This can be easily seen to be the case with digital 2D designs. With digital 3D designs it could be argued that the design needs to be applied to a physical product, but it could be also seen that actual materialization or commercialization is not necessary - a mere possibility is enough. ${ }^{125}$ Some see that creation and publication is enough to trigger URCD. ${ }^{126}$ The consequence of this would be that every digital design that is included in a

\footnotetext{
117 Case ICD 8538, Samsung Electronics Co. Limited and others v. Apple Inc. (12 June 2013) Decision of the Invalidity Division, para. 37.

118 Ibid. paras. 40-41.

119 Ibid. para. 41.

120 Ibid. para. 41.

121 Ibid. para. 41.

122 Case R 8/2008-3, Crocs, Inc. v. Holey Soles Holdings Ltd, (26 March 2010) Decision of the Third Board of Appeal, paras. 83-92.

123 Case ICD 8538, Samsung Electronics Co. Limited and others v. Apple Inc. (12 June 2013) Decision of the Invalidity Division, para. 42.

124 Tischner (2018), p. 309.

125 Nordberg and Schovsbo (2017), p. 16.

126 Elam (2016), p. 154; Nordberg and Schovsbo (2017), p. 20.
} 
game, ${ }^{127}$ video or a website can potentially be protected by URCD, provided that it is new and has an individual character. ${ }^{128}$ The publication of a game would also trigger a 12-month grace period, during which a design holder can apply for a registered design protection. ${ }^{129}$

\subsection{The Individual Character of a Digital Design}

In order to have individual character, a design needs to produce a different overall impression on the informed user. ${ }^{130}$ This difference should be clear, and the nature of the product to which the design is applied as well as the industrial sector should be taken into consideration. ${ }^{131}$ In the assessment, the degree of freedom of the designer should be taken into consideration, ${ }^{132}$ whilst protection cannot be granted if the freedom has been very limited or if features are dictated by their function. ${ }^{133}$ As the informed user and the freedom of the designer are the key factors of the individual character consideration, the paper examines these more closely in the context of digital designs.

\subsubsection{The Informed User}

The informed user is a fictional character which is used to assess a design's novelty and individual character as well as whether two designs produce different overall impressions. The CJEU has clarified that the informed user must be understood as referring, not to a user of average attention, but to a particularly observant user, based on personal experience or extensive knowledge in the field. ${ }^{134}$

The Third Board of Appeal saw the informed user of computer icons as a person who uses computer icons when playing computer games or running other types of computer programs on their computer, smartphones, or tablet; who is familiar with the different designs of computer icons and possesses a certain degree of knowledge with regard to the features that such icons normally include; and as a result of their interest in icons, shows a relatively high degree of attention when using the icons. ${ }^{135}$ Thus, the informed user is not restricted to a single type of gaming device, such as a console or phone, and can distinguish the differences between icons and designs

\footnotetext{
127 One game can contain hundreds if not thousands of individually modelled designs.

128 CDR Art. 4.

129 CDR Art. 7(2).

130 CDR Art. 6(1).

131 CDR Art. 14.

132 CDR Art. 14.

133 CDR Art. 8(1).

134 According to the CJEU, the informed user lies "somewhere between that of the average consumer, applicable in trade mark matters, who need not have any specific knowledge and who, as a rule, makes no direct comparison between conflicting trade and the sectoral expert found in patent law, who is an expert with detailed technical expertise". Case C-281/10 P, PepsiCo v. Grupo Promer Mon Graphic, ECLI:EU:C:2011:679, para. 53.

135 Case R 1951/2015-3, TeamLava, LLC v. King.com Limited, (1 December 2016) Decision of the Third Board of Appeal, Para. 42.
} 
implemented in video games. Similarly, the Invalidity Division saw that an informed user is familiar with designs of GUIs in electronic devices. ${ }^{136}$ They are aware of the designs of products which were available before the date of priority of the contested RCD as well as of the fact that the designer's freedom, and subsequently, the graphic design, do not face any substantial constraints caused by the technical requirements and the functions of the device. ${ }^{137}$ Thus, the informed user is not only familiar with prior GUI designs but also knows that the freedom of the designer is not substantially restricted. When the compared designs are different products, this should be taken into account when determining the informed user. For example, in one case, the informed user was seen as a person who is familiar both with the features of toilet rim blocks and the different designs in this field, as well as with the features of computer games and the range available on the market in this regard. ${ }^{138}$ This emphasizes the fictionality of the informed user.

To summarize, an informed user of video games and digital designs could be described as a person who uses computer games, software or digital designs often, but is not a game creator or designer; ${ }^{139}$ is familiar with the different designs used in games, whether made for mobile devices, PCs or consoles; is familiar with past designs used in games; pays relatively high attention when using these games and designs; ${ }^{140}$ can be a child or an adult; ${ }^{141}$ and, finally, knows that the designer's freedom is not restricted, but does not know when it is restricted by technical functions. $^{142}$

\subsubsection{Digital Design and the Freedom of the Designer}

According to the CJEU the greater the freedom in developing the design is, the less likely it is that minor differences will be sufficient to produce a different overall impression on an informed user. However, if the designer's freedom is greatly restricted, even minor differences can contribute to a different overall impression. ${ }^{143}$ With digital designs, the creator enjoys an almost unlimited creative freedom, which is not bound by restrictions of the physical world, such as material strength, cost or

\footnotetext{
136 Case ICD 8538, Samsung Electronics Co. Limited and others v. Apple Inc. (12 June 2013) Decision of the Invalidity Division, para. 60.

137 Ibid. para. 60.

138 Case R 2115/2015-3, Buck-Chemie GmbH v. Henkel AG \& Co. KGaA, (8 March 2017) Decision of the Third Board of Appeal, Para. 29.

139 Case C-281/10 P, PepsiCo v. Grupo Promer Mon Graphic, ECLI:EU:C:2011:679, para. 59.

140 Ibid. para. 59.

141 Ibid. para. 54; in the case of fashion dolls, the informed user could be a child or an adult who collects such toys. Case ICD 10832, Mattel, Inc. v. Jieyang Defa Industry CO., Ltd., (10 July 2019) Decision of the Invalidity Division, p. 10. It could be asked whether an age restriction in games would apply to determining the age of the informed user in a R18 + game.

142 Case T-10/08, Kwang Yang Motor v. OHIM, ECLI:EU:T:2011:446, para. 27.

143 Ibid. para. 33.
} 
availability. It can be considered that, with digital designs, the freedom of the designer is mainly restricted by the subject matter that it depicts, but in most cases, this is not very restrictive. ${ }^{144}$

With physical designs, the freedom of the designer is often restricted by the fact that the appearance of the product is solely dictated by its technical functions. ${ }^{145}$ However, what does this mean in the digital context? For example, according to the Third Court of Appeal, when it comes to computer icons, the designer's freedom can be limited to the extent that the icon must be able to be represented on a computer screen and that an icon is generally limited in size. ${ }^{146}$ It could also be considered that the freedom of the designer could be restricted by things like the need to make it visually clear, size or contrast. On the other hand, with a mobile GUI, the Invalidity Division has not seen features such as a black background, the size and contrast of icons, the division of icons according to their usage, frequency, or the presence of other elements to be considered, as being solely dictated by the technical functions pursuant to Art. 8(1) CDR. ${ }^{147}$ This is because the function of the graphical interface is to allow the user to interact with the device. Being dictated by its technical function, however, the interface would be in the form of commands rather than images. ${ }^{148}$ Thus, images make the functions accessible in a designed manner, which is not a technical but a visual matter. ${ }^{149}$ At the same time, with the CJEU rejecting the "multiplicity of forms" theory in its Doceram decision, ${ }^{150}$ it has been suggested that a GUI that is solely motivated by efficiency or intuitive use could be seen as technical and not eligible for design protection. ${ }^{151}$ For example, if a design which aims to lower the cognitive burden of using a GUI can be done in two or more ways, it can be considered to fulfil the old "multiplicity of forms" test. However, according to Doceram, if the design is solely dictated by this efficiency consideration, it may be seen as technical and excluded under Art. 8(1). ${ }^{152}$ In video games, the functionality can also be dynamic, and how the information is displayed can be intertwined with graphical expression. For example, the European Patent Office granted a patent on a way of conveying the location of the nearest teammate to a player by dynamically displaying a guide mark on the edge of the screen when

\footnotetext{
144 For example, the Invalidity Division did see that the freedom of the designer can be restricted insofar as it should resemble a human head. However, it did not see Caucasian facial features as restrictive, because there was ample freedom for the designer to create a doll resembling the head of any race, skin, colour, size, shape, or gender. Case ICD 10832, Mattel, Inc. v. Jieyang Defa Industry CO., Ltd., (10 July 2019) Decision of the Invalidity Division.

145 CDR Art. 8.

146 Case R 1951/2015-3, TeamLava, LLC v. King.com Limited, (1 December 2016) Decision of the Third Board of Appea, para. 43.

147 Case ICD 8538, Samsung Electronics Co. Limited and others v. Apple Inc. (12 June 2013) Decision of the Invalidity Division, para. 50.

148 Ibid. para. 50.

149 Ibid. para. 50.

150 Case C-395/16 Doceram GmbH v. Ceramtec GmbH, ECLI:EU:C:2018:172.

151 Shemtov (2020), p. 23.

152 Ibid. p. 23.
} 
the teammate is off-screen. ${ }^{153}$ This was seen to produce a technical effect. ${ }^{154}$ If a design application had been filed on the dynamic element of information display, it would have been rejected due to its functionality. However, the appearance of the guide mark could be protected if it fulfils the requirements of protection.

A digital design can also depict a purely functional object, and an interesting question is whether the digitalization of such object removes its functionality. For example, in the copyright context, purely functional objects, such as a screwdriver, are not protected due to the lack of originality. However, if a screwdriver were 3D modelled into a digital object, would it then be protected as an artistic work, as it is not functional in digital form? In general the answer is negative because the design is copyrightable only if something original has been added during the digitalization process. ${ }^{155}$ In the design context, similarly, digital designs of purely functional objects do not seem to attract design protection. This is because the design protection is already claimed in an immaterial form, whether it is a drawing, a picture, or a digital representation of the design. ${ }^{156}$ Its functionality can be determined in the appearance of the product that it represents. In other words, although the design is not functional in its digital form, its appearance is still determined by functionality or technical considerations, and protection can be denied on this basis. An example could be a sword. In its basic form, its appearance is determined by its function, and it is not protectable, regardless of whether it exists in a digital or a physical form. However, if a designer wants to make it a "fantasy" sword (i.e. make it decorative, oversized or just futuristic looking), this fantasy appearance can be new and have individual character, which is not determined by its function, namely sticking something with a pointy end.

There is also the question of what can be considered as normal use of a digital design because, for complex products, the perspective from which the design is used can determine its individual character. ${ }^{157}$ For example, with a lawnmower design, the court has taken a rather restrictive view from which direction the design is seen during normal use. ${ }^{158}$ Does the same apply if a lawnmower is depicted in a video game? On the other hand, it is commonly found that the normal use of digital design is looking at it on a computer, tablet or mobile phone screen. ${ }^{159}$ Thus, if a design is even briefly visible on screen, it is considered as use of that design. ${ }^{160}$ However, the

\footnotetext{
153 See the EPO (2020) Guidelines for Examination G II 3.7.2. https://www.epo.org/law-practice/legaltexts/html/guidelines/e/g_ii_3_7.htm; see also the EPO Board of appeal T 928/03 ECLI:EP:BA:2006:T092803.20060602.

154 Ibid.

155 See Antikainen and Jongsma (2017), p. 264; Osborn (2019), p. 177; see also Sect. 2.3.

156 This is also a natural interpretation in following the abstract view of protection. See Sect. 5 below.

157 Bently and Sherman (2014), p. 725.

158 The court saw that during the normal use of a lawnmower, it is placed on the ground and the user stands behind it, thus principally seeing the upper side of the engine. This upper side determined the overall impression produced by the engine design. Case T-10/08 Kwang Yang Motor Co., Ltd v. OHIM, ECLI:EU:T:2011:446, para. 22.

159 Mendis (2020), p. 452.

160 The Board of Appeal found that a design component does not need to be clearly visible at every moment of its use, but it is sufficient if the whole of the component part can be seen some of the time in such a way that all its essential features can be comprehended. See Case R 690/2007-3, Lindner
} 
way in which digital designs are used is changing due to the development of new technologies, such as virtual reality, augmented reality and holograms. These technologies transform the use of digital designs closer to the tangible world. With augmented reality glasses, for example, a digital design can be projected over a table and examined from different perspectives. These technologies blur the line between physical and virtual space, thus broadening what can be considered normal use and the overall impression of the digital design.

\section{The Scope of Protection and Digital Conversion}

\subsection{Towards an Abstract View of Protection}

The final issue to consider is the scope of protection. Design law gives broad exclusivity to the holder of the RCD. In addition to the making, offering, putting on the market, importing and exporting, the exclusivity also covers the mere using of a design. ${ }^{161}$ The protection includes any design that does not produce a different overall impression to an informed user, assessed in consideration of the degree of freedom of the designer in developing the design. ${ }^{162}$ The scope of protection and, in the end, the test for design infringement mirror the test to determine the individual character. ${ }^{163}$ The concepts and the questions asked are similar to the individual character consideration. ${ }^{164}$ Although the design claim plays an important role in determining the scope of protection, ${ }^{165}$ it is not affected by the product or the classifications to which the design is applied or incorporated. ${ }^{166}$ Similarly, the design infringement is not confined to the same product to which the design was first applied or used. ${ }^{167}$ Thus, a design for a lamp can be infringed if it is incorporated in a stool, provided that it produces a similar overall impression to an informed user. With the URCD, however, the exclusivity covers only protection against direct copying, but not if the copying is a result of an independent work of creation by a designer who may be reasonably thought not to be familiar with the design made available to the public by the holder. ${ }^{168}$

Footnote 160 continued

Recyclingtech v. Franssons Verkstäder (22 October 2009) Decision of the Third Board of Appeal, para. 21.

161 CDR Art. 19(1).

162 CDR Art. 10; see Sect. 4.2.1 above.

163 Stone (2016), p. 206; Bently and Sherman (2014), p. 758; Case C-448/10, Celaya Emparanza y Galdos Internacional SA v. Proyectos Integrales de Balizamiento SL, ECLI:EU:C:2012:88, para. 52).

164 Bently and Sherman (2014), p. 758; Margoni (2018), p. 15.

165 Tischner (2019), p. 169; Tischner (2018), p. 309; see also Magmatic Ltd v. PMS International Ltd [2016] UKSC 12.

166 CDR Art. 36(6).

167 Case C-281/10 P, Pepsi Co. v. Grupo Promor \& OHIM, ECLI:EU:C:2011:679; Green Lane Products Ltd. v. PMS International Group Plc., EWCA Civ 358 (2008), Bently and Sherman (2014), p. 755.

168 CDR Art. 19(2). 
It is generally seen that the "use" and, thus, the scope of protection include both the tangible and intangible forms of exploitation, ${ }^{169}$ but it is not clear cut to what extent. As discussed in the introduction, in the EU there exist "abstract" and "concrete" views regarding the scope of protection. Some see that the scope of protection is rather narrow or "concrete", that the protection is tied to the actual shape and physical reproduction of a design. For example, a design that solely claims shape is only infringed by a product that is made in that shape. ${ }^{170}$ In other words, a 3D product, such as a design of a car or a chair would not be infringed by the use on 2D products, such as posters or postcards. This is because the design's 3D shape is not applied to the $2 \mathrm{D}$ object. ${ }^{171}$ Also, it could be argued that the immaterial use of a physical product is not infringing, as there is no product. ${ }^{172}$ It has been also suggested that "use" does not cover broadcasting ${ }^{173}$ or that broadcasting only covers 2D designs. ${ }^{174}$

Case law, however, suggests a rather broad, "abstract" interpretation of the scope of protection. In a German design case, the German Federal Supreme Court held that the use of a train's image in a competitor's brochure infringed the owner of the Community's design right in the shape of the train, and this use did not fall under the limitations of citations. ${ }^{175}$ The original protection was for a 3D design but in this decision the use of the design also covered use in 2D format. Thus, a 2D use of a 3D design can be considered as infringement. ${ }^{176}$ Similarly, in a French case, using a protected design of an umbrella in an advertisement photograph for hair products was found to be infringing, as the photograph that showed the design did not confer a different overall impression. ${ }^{177}$

These views are partially confirmed by the CJEU. In the Nintendo v. BigBen case $^{178}$ a company sold and used images of goods corresponding to a protected design held by Nintendo. Nintendo found that the sale of these goods infringed on its registered Community design. In addition, Nintendo claimed that the company had no right to use the images of the goods corresponding to the design in question for their commercial activity. ${ }^{179}$ The CJEU was asked whether Art. 20(1)(c) of the CDR should be interpreted as meaning that a third party may depict a Community

\footnotetext{
169 Kapyrina (2018), p. 44. For example, Art. 26 of the TRIPS Agreement covers only material exploitation of a design but member states are free to provide additional protection to right holders.

170 Bently and Sherman (2014), p. 759.

171 Ibid. p. 759.

172 McKenna and Osborn (2020), p. 395; Bently and Sherman (2014), p. 710; Margoni (2013), p. 232; Elam (2016), p. 151; Mendis (2020), p. 456.

173 Bently and Sherman, p. 755.

174 Margoni (2013), p. 232.

175 German Federal Supreme Court, April 7, 2011 - I ZR 56/09- ICE, GRUR 2011, 1117; Bardhele Pagenberg IP Report 2011 V, 28.

176 Stone (2016), p. 470; Nordberg and Schovsbo (2017), p. 9.

177 Paris Court of Appeal, pôle 5, ch. 2, 27 Nov. 2015, S.A.S. Piganiol c/S.A.S. Publicis Conseil et al., No. 13/21612, JurisData No. 2015-029315; Propr. Industr. No. 2, févr. 2016, comm. 13, Greffe P; see also Kapyrina (2018), p. 51.

178 Joined cases C-24/16 and 25/16, Nintendo v. BigBen, ECLI:EU:C:2017:724.

179 Ibid.
} 
design for commercial purposes if it intends to sell accessory items to the right holder's goods, corresponding to the Community design, and if so, what criteria would apply to this. Thus, in essence, the question was whether the use of a $2 \mathrm{D}$ image of a 3D design on a webpage may be an act of reproduction, subject to exceptions such as citation right. The Court's answer to this was affirmative, that a $2 \mathrm{D}$ representation of a product corresponding to a Community design may constitute a reproduction, but that it can also be the subject of the exception given in Art. 20(1)(c). ${ }^{180}$ Thus, depicting an image of a product protected by design can constitute an infringement. This means that the CJEU has chosen the "abstract" view of protection over the "concrete" and thus the scope of protection also covers digital conversion. A consequence of this is that depicting an image of a product protected by design in a brochure constitutes an infringement even if the product has not yet been made. ${ }^{181}$ In the following, the paper considers how this "abstract" view confers to the use of digital designs in the video game industry.

\subsection{Using Digital Design Physically}

Making a digital design into a physical object can be considered to easily fall within the scope of protection, as it can be considered as use of the design. ${ }^{182}$ As mentioned above, the scope of protection is not affected by the product classification in which the design is applied or in which it was first applied or used. ${ }^{183}$ The protection concerns the appearance of the product, thus, if the registered design were a computer icon and if it produced a similar overall impression to an informed user, printing the icon on wallpaper or showing it in a cartoon would infringe on the right holder's design right. Although it is difficult to see how animated icons could be reproduced into physical objects as such, the design claim can consist of a series of pictures that illustrate the animation. Printing a single frame from the animation could be seen as infringing.

Similarly, infringement can occur when a physical copy is made of a digital 3D design. This would be the case even if digital designs could not be considered as products. For example, a digital model of a fantasy car or a toy can be registered in Locarno Class 21.04 (toys and games), and when it is printed or manufactured, it manifests itself as a physical product. In the Trunki case, the design was graphically presented as a greyscale CAD model, and the infringement comparison was done between this CAD model and the alleged infringing physical model. ${ }^{184}$ Also, in the light of recent case law $^{185}$ it can be asked whether applying a digital 3D design on a t-shirt or in a leaflet, for example, could be seen as an infringing act. In the case of URCD, a physical reproduction of a digital design can be considered infringing, because the right can materialize just by adding a design to a game and making it

\footnotetext{
180 Ibid. para. 69.

181 Nordberg and Schovsbo (2017), p. 9.

182 CDR Art. 19.

183 CDR Art. 36(6).

184 Magmatic Ltd v. PMS International Ltd [2016] UKSC 12.

185 See Sect. 5.1 above.
} 
available to the public. ${ }^{186}$ However, infringement happens only if it is a product of deliberate copying as opposed to of independent creation. ${ }^{187}$

\subsection{Using Physical Design Digitally}

A more relevant, but also more complicated, situation for the gaming industry is when a design made for a physical object is converted into a digital game. The problem is tied to a question of whether there is "use" of a product in a different format or when the use is immaterial. Bently and Sherman illustrate this problem by asking whether it can be seen as use if a design-protected cartoon character is broadcast on television or placed on a website. ${ }^{188}$ Recital 21 of the Design Regulation states that the right "should also extend to trade in products embodying infringing designs", ${ }^{189}$ which could be seen supporting the view that the meaning of "use" is to be confined to the use of physical products, and it would, thus, neither cover broadcasting nor online use. ${ }^{190}$ However, the definition of design does indicate that the appearance of a graphic symbol should be protected. ${ }^{191}$ Confining the use to material products, rather than immaterial media, such as the internet, seems limiting and would also exclude web designs from the field of design law. ${ }^{192}$ Margoni has also questioned whether the term "publication" is limited to 2D designs, such as ornaments, but sees as plausible that, as long as the outer appearance of a product is communicated to the public, this is sufficient to trigger the legal effects of CD. ${ }^{193}$ The CJEU has now clarified this situation and use includes both transformative use and use on a web page, at least in a situation where the original physical design is in $3 \mathrm{D}$, which is then transformed into 2D. ${ }^{194}$ The EUIPO practice seems to confirm this, ${ }^{195}$ and if the scope of protection did not include use in digital form, such as in a video game or on the internet, there would be little use for it in the gaming industry. ${ }^{196}$

The situation is somewhat more complicated with digital 3D designs. A strict interpretation would require the product to be an industrial or handicraft item and, thus, infringement could only happen through the use of a physical product. ${ }^{197}$ This, however, is seen by many as overly restrictive due to the current technological

\footnotetext{
186 See Sect. 4.1 above.

187 CDR Art. 19(2).

188 Bently and Sherman (2014), p. 755.

189 CDR Art. 21.

190 Bently and Sherman (2014), p. 755.

191 See Sect. 3.2.1 above.

192 Bently and Sherman (2014), p. 755 subnote 56.

193 Margoni (2013), p. 232.

194 Joined cases C-24/16 and 25/16, Nintendo v. BigBen, ECLI:EU:C:2017:724. See supra note 178 and accompanying text.

195 Case R 1950/2015-3, TeamLava, LLC v. King.com Limited, (1 December 2016) Decision of the Third Board of Appeal; Case R 1949/2015-3, TeamLava, LLC v. King.com Limited, (1 December 2016) Decision of the Third Board of Appeal.

196 Recital 15 of the CDR states that Community design should serve the needs of all sectors of industry in the Community.

197 Elam (2016), p. 160; Margoni (2013), p. 231.
} 
change, which blurs the line between digital and physical use. ${ }^{198}$ Due to the BigBen decision, it is hard to conclude that digital use would be explicitly excluded. The question is, if the use of a $2 \mathrm{D}$ picture of a $3 \mathrm{D}$ product can be considered as use, then why not a 3D picture of a 3D product? ${ }^{199}$ Some scholars agree with this and see that reproducing and converting a design into a digital format should constitute an infringement. ${ }^{200}$ They understand the standard of protection broadly, which means that already scanning or modelling implies making a copy of the design. ${ }^{201}$ Also, as far as the act of creation of the design is considered, the law is neutral on the technical method, whether it is creating a drawing by hand or by using a computer program. ${ }^{202}$ Thus, if creating a digital model can be considered an act of use, then also uploading that same file to an online repository would constitute a separate infringement of the design. ${ }^{203}$ Others have presented an opposing view, arguing that the use of a physical design appearance on a monitor should not be seen as tantamount to an act of infringement. ${ }^{204}$ This is for two reasons: first, as discussed above, it could be argued that there is no use of the product as there is only appearance without the product; ${ }^{205}$ second, even if it is assumed that there is a product, the overall impression on the informed user is different, as few would confuse a physical product such as a screwdriver with a digital product. ${ }^{206}$ This point is elaborated further below.

\subsection{The (Confused) Informed User and the Similar Overall Impression}

In the end, we need to ask whether simply digitization would give a different overall impression of a product to an informed user, and whether an informed user, or any person for that matter, could confuse a virtual object with a physical object. In the context of US design patents, at least one case seems to indicate that there would be no confusion. Here, the US court had to consider whether a virtual 3D design infringed a design patent. $^{207}$ The alleged infringed design patent concerned the design of a stun gun in the shape of brass knuckles. The holder of the design patent argued that Activision's video game "Call of Duty: Black Ops II" included a virtual stun gun weapon that could be held as brass knuckles in the game, and that this infringed on their design patent. It should be noted that when visually examined, these two designs looked nothing alike. However, instead of focusing on visual differences, the court dismissed the case stating that no reasonable person would purchase the defendant's video game believing that they were purchasing the

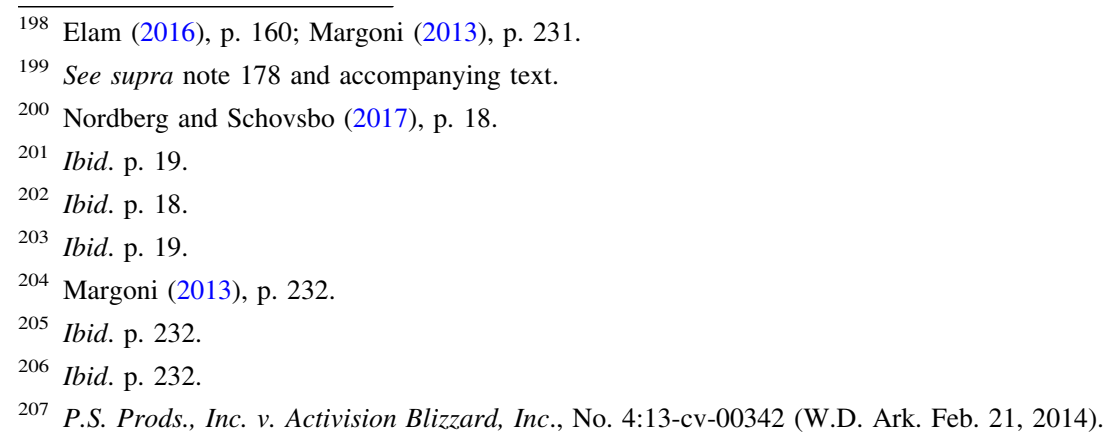


plaintiff's stun gun. ${ }^{208}$ Thus, the court reasoned that no reasonable person would have confused the virtual with the real one. However, it is difficult to exclude confusion completely, especially in the case when the digital image's sole purpose is to exactly replicate an existing design. ${ }^{209}$ For example, many of the pictures of mobile phones in advertisements are, in fact, 3D-rendered pictures instead of photographs of physical phones. Also, in films it is now difficult to distinguish what has been added digitally and what is real.

On the other hand, according to EU design law, it is not about whether a person would genuinely confuse a virtual object with the real one, but whether an informed user gets a similar overall impression from the appearances of two designs. ${ }^{210}$ As discussed above, the informed user in the context of a video game can be considered as a person who uses games, software or digital designs often, pays relatively high attention to them, and is familiar with different and past designs used in the games. ${ }^{211}$ It is likely that such a user would not genuinely confuse the digital design from the physical in a manner that they would not be able to differentiate between them. $^{212}$ The user may, however, very well get a similar overall impression from the appearance of the designs. This is also suggested by EUIPO practice where a picture of a confectioner in a book - a physical product - was seen to produce a similar overall impression on an informed user as an animated icon - a digital item. ${ }^{213}$ The EUIPO also rejected the holder's argument that a different overall impression inevitably results from the differences in the contexts in which the products in question are used, one being for sweets and one for a mobile game. ${ }^{214}$ Given that the different overall impression is considered similar to both individual character and the scope of protection, ${ }^{215}$ physical as well as digital designs can produce a similar overall impression on an informed user. Thus, a digital design can infringe a physical design. A digital copy of a physical design literally differs from it only in immaterial detail - by being digital. ${ }^{216}$

\section{Limitations and Exceptions in Using Digital Designs}

As has been stated above, using a protected physical design in a game, even for a short while, can constitute an act of infringement. In fact, any digital use of any protected design, whether registered or unregistered, could be potentially seen as

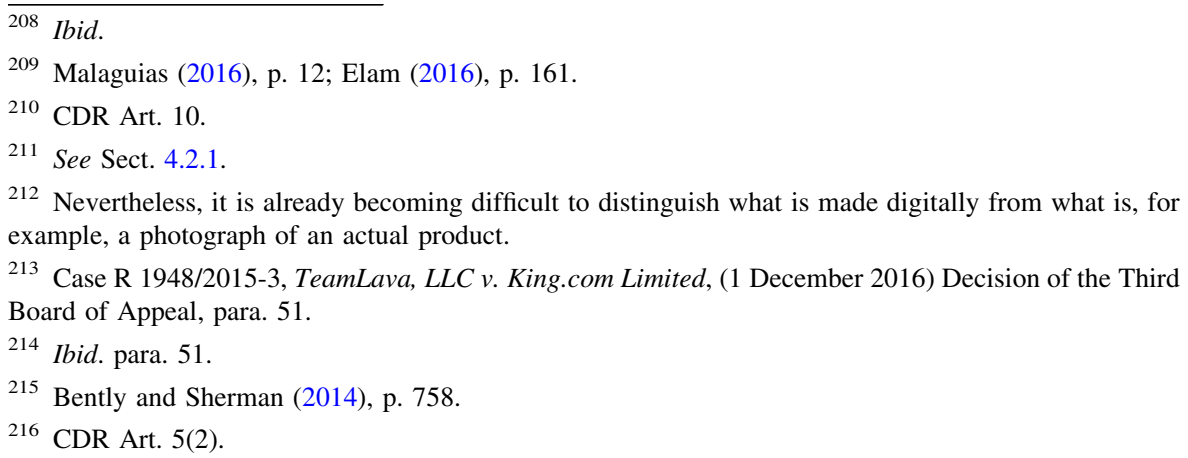


infringement. This creates a difficult situation for game creators who want to use existing designs in their games, and so the situation can be seen as overly restrictive from the viewpoint of artistic freedom. Of the limitations provided by the CDR, the most suitable would be Art. 20(1)(c), which limits the rights conferred by CD in respect of acts of reproduction for the purpose of making citations, provided that such acts are compatible with fair trade practice and do not unduly prejudice the normal exploitation of the design, and that mention is made of the source.

As mentioned above, in the German case, use of images of design (using protected trains in a brochure to advertise a company's services) was not seen as a form of citation. ${ }^{217}$ This was because the use in the brochure was solely for marketing purposes, and did not "serve any intellectual debate". ${ }^{218}$ However, in the BigBen case, the CJEU interpreted the citation right more broadly. ${ }^{219}$ It found that using images of design-protected products on a website in order to sell accessories for those same products was reproduction that was covered by the design right. ${ }^{220}$ The court saw that citation happens when a third party lawfully sells goods indented to be used with specific goods corresponding to the Community Design, and reproduces the latter in order to explain or demonstrate the joint use of the goods it sells. ${ }^{221}$ Such use was seen as acceptable by the court, because preventing an undertaking from using images of existing products for the lawful sale of its own products, in order to explain or demonstrate the joint use of the two categories of products, could discourage innovation. ${ }^{22}$ However, this limitation needs to fulfil three cumulative conditions: fair trade practice, the absence of undue prejudice to the normal exploitation of the design on account of such acts, and a mention of the source. $^{223}$

It is unclear to what extent the citation limitation can be applied to digital games, but it is definitely not applicable in every case. Using an existing design in a game could be seen as analogous to placing a design in a movie. This most likely fulfils the conditions of fair-trade practice and the use would not unduly prejudice the normal exploitation of the design. ${ }^{224}$ How the source should be mentioned in films or video games is, however, a bit unclear. At the same time, the citation right cannot apply to designs made for video games, such as video game characters or icons, as use in a digital context would at least prejudice the normal exploitation of the design. It will be difficult to make this distinction as long as the normal ways of exploitation of a design are expanding at the moment. A design can be made with

\footnotetext{
217 German Federal Supreme Court, April 7, 2011 - I ZR 56/09 - ICE, GRUR 2011, 1117; Bardhele Pagenberg IP Report 2011 V, 28.

218 Ibid; Stone (2016), p. 491.

219 Joined cases C-24/16 and 25/16, Nintendo v. BigBen, ECLI:EU:C:2017:724.

220 Ibid.

221 Ibid. para. 77.

222 Ibid. paras. 73 and 76.

223 Ibid.

224 If this is not the case, then every film which shows any protected design would potentially infringe on the design right.
} 
both physical and digital use in mind. Some scholars see the scope of limitations as too narrow for the new uses enabled by the technological development. ${ }^{225}$

While Art. 20 of the CDR gives an exhaustive list of limitations, the courts might need to rely on the freedom of expression set by Art. 10 of the European Convention on Human Rights. In the famous Plesner v. Louis Vuitton Malletier case, Luis Vuitton had registered a design for a canvas pattern, which was then used by the artist Nadia Plesner in her work titled "Simply Living". 226 The work showed an African child holding a handbag with the protected Louis Vuitton canvas. The Court of the Hague found that such use was allowed, as well as the use of the same drawing on a T-shirt. ${ }^{227}$ The court saw that the use of the design did not serve a mere commercial purpose, and the intention was not to free-ride on Louis Vuitton's reputation in a commercial sense. ${ }^{228}$ Rather, Plesner used Luis Vuitton's reputation to pass her message of social criticism and such a well-known company should accept critical use of their designs. ${ }^{229}$ The writer's view is that video games can be considered as a form of art that can contain messages of social criticism and, thus, the freedom of expression can apply to them, as well. However, this is not applicable to all situations. For example, including a famous design from another video game could be considered just free-riding and serving mere commercial purposes. Also, proving the critical use of a design can be difficult.

A partial solution for some of the problems discussed above could be aligning the limitations and exceptions of the design right with copyright. EU copyright law presents a broad list of exceptions and limitations that can give freedom to the creators and users of digital designs, whereas many of these are not present in EU design law. For example, Art. 5 of the InfoSoc Directive enables Member States to offer a quotation right, which would enable the following: using digital designs for the purposes of criticism or reviews; using digital design in public spaces; incidental inclusion of a digital design in other works; using digital designs for the purpose of advertising a public exhibition or sale of artistic works; and using a digital design for the purpose of caricature, parody, or pastiche. While there are still limits to and uncertainty about what exceptions and limitations are allowed in the digital context, ${ }^{230}$ copyright still establishes some breathing space for digital designers. Alignment would ease some of the problems created by the digitalization of designs and the cumulation of copyright and design right. ${ }^{231}$ In addition, aligning would prevent escaping specific limitations and exceptions in one system at the expense of

\footnotetext{
225 Kur (2019), p. 16-18.

226 District Court of the Hague, May 4, 2011, Nadia Plesner Joensen/Louis Vuitton Malletier SA, IER $2011 / 39$.

227 Ibid.

228 Ibid. para. 4.8.

229 Ibid. para. 4.8.

230 For example, exceptions and limitations in the EU do not seem to allow Let's Play videos, where a player streams the playthrough of a game and his reaction but does not review or criticize the game. However, most game companies allow this for the sake of publicity.

231 Kur (2019), p. 16-17; Derclaye (2020a), p. 16.
} 
the other. ${ }^{232}$ For example, parody use of digital design in a video game could be claimed as infringing due to the lack of exception, whereas in copyright this could normally be seen as acceptable.

\section{Conclusions}

This paper has considered the legal status of digital designs from the perspective of EU design law, specifically whether the protection is tied to the reproduction of physical products, and whether the scope of this protection covers dimensional conversion, such as using a 3D design in $2 \mathrm{D}$ form or vice versa. This problem was tied to two diverging views in the EU on the scope of protection in design law. The paper has argued that we have now reached a point where, under CJEU jurisprudence and EUIPO practice, most of the open questions regarding the protection of digital designs and dimensional conversion can be considered as solved. Whether they are in 2D or 3D form, digital designs can be seen as products and protected subject matter. Further, displaying a digital design in a digital game, video or on a webpage, even for a short while, makes it public but can also be enough to trigger URCD. Most importantly, the paper has shown that the CJEU has now chosen "abstract" protection over "concrete", thus broadening the scope of protection. The outcome of this is that design protection covers the digital use of design, and that the digital use of physical design, whether in 2D or 3D form, can be infringing. Only the act of digitalizing a physical object is not enough to produce a different overall impression to an informed user. This emphasizes the importance of exceptions and limitations in design law, and shows that more care should be put on these in future considerations.

Acknowledgements The author is very grateful to Professor Annette Kur (Max Planck Institute for Innovation and Competition) and Professor Nari Lee (Hanken School of Economics), as well as two anonymous reviewers, for their insightful comments on earlier drafts.

Open Access This article is licensed under a Creative Commons Attribution 4.0 International License, which permits use, sharing, adaptation, distribution and reproduction in any medium or format, as long as you give appropriate credit to the original author(s) and the source, provide a link to the Creative Commons licence, and indicate if changes were made. The images or other third party material in this article are included in the article's Creative Commons licence, unless indicated otherwise in a credit line to the material. If material is not included in the article's Creative Commons licence and your intended use is not permitted by statutory regulation or exceeds the permitted use, you will need to obtain permission directly from the copyright holder. To view a copy of this licence, visit http:// creativecommons.org/licenses/by/4.0/.

232 Kur (2019), p. 16. 


\section{References}

Antikainen M, Jongsma D (2017) The art of CAD: copyrightability of digital designs files. In: Ballardini R-M, Norrgård M, Partanen J (eds) 3D printing, intellectual property and innovation - insights from law and technology. Wolters Kluwer, Alphen aan den Rijn, pp 257-274

Adams M, Webster E (2016) "Design" is a fashionable term - but what does it really mean? https:// theconversation.com/design-is-a-fashionable-term-but-what-does-it-really-mean-56368. Accessed 25 Nov 2019

Bently L, Sherman B (2014) Intellectual property law, 3rd edn. Oxford University Press, Oxford

Brandes K (2012) Design protection in the United States and European Union: piracy's detrimental effects in the digital world. Brook J Int'l L 37(3):1115-1137

Burstein S (2015) The patented design. Tenn Law Rev 83:161-230

Church O, Estelle D, Stupfler G (2019) An empirical analysis of the design case law of the EU Member States. IIC 50(6):685-719

Corbett S (2016) Videogames and their clones - how copyright law might address the problem. CLSR Int J Technol Law Pract 32:615-622

Derclaye E (2018) The copyright/design interface - past, present and future. Cambridge University Press, Cambridge

Derclaye E (2020a) Doceram, Cofemel and Brompton: how does the current and future CJEU case law affect digital designs? In: Pasa E (ed.) Il design, l'innovazione tecnologica e digitale, Un dialogo interdisciplinare per un ripensamento delle tutele - Design, technological and digital innovation. Interdisciplinary proposals for reshaping legal protections. ESI Press, Naples. Forthcoming 2020, Available at SSRN: https://ssrn.com/abstract=3507802

Derclaye E (2020b) The CJEU decision in Bromton Bicycle - a welcome double rejection of the multiplicity of shapes and causality theories in copyright law. Kluwer Copyright Blog. http:// copyrightblog.kluweriplaw.com/2020/06/25/the-cjeu-decision-in-brompton-bicycle-a-welcomedouble-rejection-of-the-multiplicity-of-shapes-and-causality-theories-in-copyright-law/?doing_wp_ cron=1597832239.4026639461517333984375\#comments. Accessed 1 Sep 2020

Elam V (2016) CAD files and European design law. JIPITEC 7(2):145-162

EPO (2020) Guidelines for Examination in the European Patent Office

EUIPO (2018) Guidelines for Examination of Registered Community Designs. Examination of Applications for Registered Community Designs

Ferril E (2016) Could a "real" design solve a "virtual” problem? Protecting innovative design against physical or online infringing products. https://www.finnegan.com/en/insights/could-a-real-designsolve-a-virtual-problem-protecting.html. Accessed 20 Nov 2019

Filitz R, Henkel, J, Ohnemus J (2017) Digital design protection in Europe: law, trends, and emerging issues. ZEW Discussion Paper No. 17-007

Heskett J (2005) Design: a very short introduction. Oxford University Press, Oxford

Kapyrina N (2018) Limitations in the field of designs. IIC 49:41-62. https://doi.org/10.1007/s40319-0170660-4

Kur A (2019) Unité De L'Art is here to stay - Cofemel and its consequences. Max Planck Institute for Innovation \& Competition Research Paper No. 19-16

Kur A (2003) Protection of graphic user interfaces under European design legislation. IIC 34(1):50-62

Malaguias P (2016) Consumer 3D printing: is the EU copyright and design law framework fit for purpose? Queen Mary J Intellect Prop 6(3):321-430

Margoni T (2018) Design rights and 3D printing in the UK - balancing innovation and creativity in a (dis)harmonized and fragmented legal framework. In: Mendish D, Lemley M, Rimmer M (eds) 3D printing and Beyond: the intellectual property and legal implications surrounding 3D printing and emerging technologies. Edward Elgar, Cheltenham, pp 77-98

Margoni T (2013) Not for designers: on the inadequacies of EU design law and how to fix it. JIPITEC 3:225-248

Massa C, Strowel A (2003) Community design: Cinderella revamped. EIPR 25(2):68-78

McArthur A (2013) Clone Wars: the five most important cases every game developer should know. https://www.gamasutra.com/view/feature/187385/clone_wars_the_five_most_.php. Accessed 13 Nov 2019

McKenna M, Osborn L (2020) Trade mark protection for digital goods. In: Aplin T (ed) Research handbook on intellectual property and digital technologies. Edward Elgar, Cheltenham, pp 382-396 
Mendis D (2020) Fit for purpose? 3D printing and the implications for design law: opportunities and challenges. In: Aplin T (ed) Research handbook on intellectual property and digital technologies. Edward Elgar, Cheltenham, pp 445-463

Musker DC (2001) The design directive. The Chartered Institute of Patent Agents, Thornton

Nordberg A, Schovsbo J (2017) EU design law and 3D printing: finding the right balance in the new e-ecosystem. In: Ballardini R-M, Norrgård M, Partanen J (eds) 3D printing, intellectual property and innovation - insights from law and technology. Wolters Kluwer, Alphen aan den Rijn, pp 275-302

Oesch R, Rinkineva M-L, Hietamies H, Puustinen K (2005) Mallioikeus: muotoilun suoja. Talentum, Helsinki

Ohly A (2018) The case for partial cumulation in Germany. In: Derclaye E (ed) The copyright/design interface - past, present and future. Cambridge University Press, Cambridge, pp 128-170

Osborn L (2019) 3D printing and intellectual property. Cambridge University Press, Cambridge

Rawsthorn A (2008) What defies defining, but exists everywhere? https://www.nytimes.com/2008/08/18/ arts/18iht-DESIGN18.1.15325667.html. Accessed 13 Nov 2019

Remedy (2017) Creating a character's look. https://www.remedygames.com/creating-a-characters-look/. Accessed 13 Nov 2019

Rodrigues J (2018) The importance of the intellectual property in the gaming industry. https://inventa. com/en/news/article/321/the-importance-of-the-intellectual-property-in-the-gaming-industry. Accessed 13 November 2019

Sanft J (2017) Get your IP game on: intellectual property protection and video games. https://www. thebrandprotectionblog.com/get-your-ip-game-on-protection-video-games/. Accessed 13 November 2019

Schovsbo J (2020) Copyright and design law: what is left after all and Cofemel? - or: design law in a 'double whammy' (January 14, 2020). Available at SSRN: https://ssrn.com/abstract=3519156

Schovsbo J, Rosenmeier M (2018) The copyright/design interface in Scandinavia. In: Derclaye E (ed) The copyright/design interface - past, present and future. Cambridge University Press, Cambridge, pp 108-127

Schovsbo J, Teilmann-Lock S (2016) We wanted more Arne Jacobsen chairs but all we got was boxes experiences from the protection of designs in Scandinavia from 1970 till the Directive. IIC 47(4):418-437

Shemtov N (2020) Software and graphical user interfaces. In: Aplin T (ed) Research Handbook on Intellectual Property and Digital Technologies. Edward Elgar, Cheltenham, pp 2-25

Smyth D (2013) How is the scope of protection of a registered Community design to be determined? JIPLP 8(4):270-272. https://doi.org/10.1093/jiplp/jpt004

Statement of the Finnish Copyright Council TN:2016:15

Stone D (2016) European Union design law - a practitioner's Guide, 2nd edn. Oxford University Press, Oxford

Suthersanen U (2011) Function, art and fashion: do we need the EU design law? School of Law Legal Studies Research Paper No. 88/2011. Queen Mary University of London

Tischner A (2019) Lost in communication: a few thoughts on the object and purpose of the EU design protection. In: Frankel Susy (ed) The Object and Purpose of Intellectual Property. ATRIP Intellectual Property Series. Edward Elgar, Cheltenham, pp 154-181

Tischner A (2018) The role of unregistered rights - a European perspective on design protection. JIPLP 13(4):303-314

\section{Case law}

Apple Computer Inc. v. Design Registry, FCR [2002] ECDR 19 (Chancery Division)

Apple Computer, Inc. v. Microsoft Corp., 35 F.3d 1435 (9th Cir. 1994)

Case C-5/08, Infopaq v. Danske Dagblades Forening, ECLI:EU:C:2009:465

Case C-145/10, Painer v. StandardVerlags GmbH, ECLI:EU:C:2013:138

Case C-281/10 P, PepsiCo v. Grupo Promer Mon Graphic, ECLI:EU:C:2011:679

Case C-310/17 Levola Hengelo v. Smilde Foods, ECLI:EU:C:2018:899

Case C-355/12 Nintendo v. PC Box, ECLI:EU:C:2014:25

Case C-393/09, Bezpečnostní softwarová asociace - Svaz softwarové ochrany v. Ministerstvo kultury, ECLI:EU:C:2010:816 
Case C-395/16, Doceram GmBH v. Ceramtec GmBH, ECLI:EU:C:2018:172

Case C-448/10, Celaya Emparanza y Galdos Internacional SA v. Proyectos Integrales de Balizamiento SL, ECLI:EU:C:2012:88

Case C-604/10, Football Dataco v. Yahoo!, ECLI:EU:C:2012:115

Case C-683/17, Cofemel v. G-Star Raw, ECLI:EU:C:20219:721

Case C-833/18, SI, Brompton Bicycle Ltd v. Chedech/Get2Get, ECLI:EU:C:2020:461

Case ICD 10832, Mattel, Inc. v. Jieyang Defa Industry CO., Ltd., (10 July 2019) Decision of the Invalidity Division

Case ICD 8538, Samsung Electronics Co. Limited and others v. Apple Inc. (12 June 2013) Decision of the Invalidity Division

Case R 1948/2015-3, TeamLava, LLC v. King.com Limited, (1 December 2016) Decision of the Third Board of Appeal

Case R 1949/2015-3, TeamLava, LLC v. King.com Limited, (1 December 2016) Decision of the Third Board of Appeal

Case R 1950/2015-3, TeamLava, LLC v. King.com Limited, (1 December 2016) Decision of the Third Board of Appeal

Case R 1951/2015-3, TeamLava, LLC v. King.com Limited, (1 December 2016) Decision of the Third Board of Appeal

Case R 2115/2015-3, Buck-Chemie GmbH v. Henkel AG \& Co. KGaA, (8 March 2017) Decision of the Third Board of Appeal

Case R 690/2007-3, Lindner Recyclingtech v. Franssons Verkstäder (22 October 2009) Decision of the Third Board of Appeal

Case R 8/2008-3, Crocs, Inc. v. Holey Soles Holdings Ltd, (26 March 2010) Decision of the Third Board of Appeal

Case T-10/08, Kwang Yang Motor v. OHIM, ECLI:EU:T:2011:446

Decision of the Finnish Market Court MAO:302/18

District Court of the Hague, May 4, 2011, Nadia Plesner Joensen/Louis Vuitton Malletier SA, IER 2011/39

EPO Board of appeal T 928/03 ECLI:EP:BA:2006:T092803.20060602

German Federal Supreme Court, 4 May 2000, Case No. I ZR 256/97, GRUR 2001, 51, 52

German Federal Supreme Court, April 7, 2011 - I ZR 56/09 - ICE, GRUR 2011, 1117; Bardhele Pagenberg IP Report 2011 V, 28

Green Lane Products Ltd. v. PMS International Group Plc., EWCA Civ 358 (2008)

Joined cases C-24/16 and 25/16, Nintendo v. BigBen, ECLI:EU:C:2017:724

Joined cases C-403/08 and C-429/08, Premier League Ltd and Karen Murphy, ECLI:EU:C:2011:631

Magmatic Ltd v. PMS International Ltd [2016] UKSC 12

Paris Court of Appeal, November 27, 2015, pôle 5, ch. 2, S.A.S. Piganiol c/ S.A.S. Publicis Conseil et al., no 13/21612, JurisData no 2015-029315; Propr. Industr. no 2, févr 2016, comm. 13, Greffe P

P.S. Prods., Inc. v. Activision Blizzard, Inc., No. 4:13-cv-00342 (W.D. Ark. Feb. 21, 2014)

Publisher's Note Springer Nature remains neutral with regard to jurisdictional claims in published maps and institutional affiliations. 